\section{ASIAN/NORTH AFRICAN LIBRARIANS TO FORM NEW SUBSECTION}

A group of librarians who specialize in the development of Asian and North African collections have announced their intention to form a new subsection within the Subject Specialists Section of the Association of College and Research Libraries. The purposes of the new subsection are to provide a forum for discussion of mutual problems and concerns shared by librarians specializing in these fields and to establish an organ which can act for the Association of College and Research Libraries Subject Specialists Section, in collaboration with other professional groups, with respect to those aspects of library service requiring knowledge of Asian and North African languages and area studies.

Librarians who are interested in joining the new subsection are warmly welcomed to do so. An organizational meeting to determine the name of the subsection, draft bylaws and elect a slate of permanent officers will be convened during the annual conference of the American Library Association, to be held in Atlantic City during June 22-28, 1969. The exact time and place of the organizational meeting will be announced later. Those who are interested in joining the new subsection are invited to contact the Chairman of the ad hoc Organizing Committee: Mr. Louis A. Jacob, Director, Asian Reference Department, Van Pelt Library, University of Pennsylvania, Philadelphia, Pennsylvania 19104.

\section{QUESTIONNAIRES FOR PHOTODUPLICATION DIRECTORY}

A revised edition of Directory of Library Photoduplication Services, edited by Cosby Brinkley, is in preparation. It will include selected data on interlibrary loan practices, as well as on photocopy services. Questionnaires are being mailed to libraries with substantial activities in these areas. Libraries not receiving the questionnaire and wishing to be considered for inclusion may obtain the form from: Mr. Cosby Brinkley, Photoduplication Service, Swift Hall, University of Chicago, Chicago, Illinois 60637.

ACRL membership Jan. 31, 1969 . 13,655

Jan. 31, $1968,13,020$

Jan. 31, 1967 . 11,627

Jan. 31, $1966 \quad 10,277$

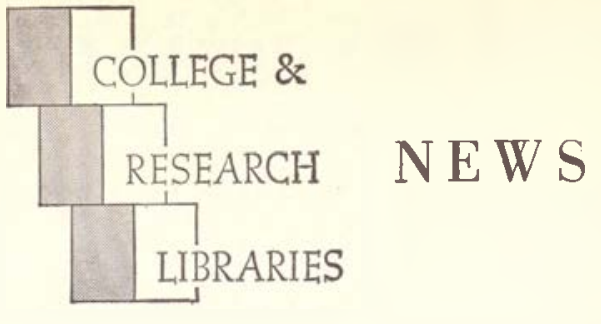

ACRL News Issue of College \& Research Libraries

Editor, David Kaser, Cornell University Libraries, Ithaca, N.Y. 14850.

Managing Editor, Mary Falvey, 50 E. Huron St., Chicago 60611.

News Editor, David Doerrer, Cornell University Libraries, Ithaca, N.Y. 14850.

Editorial Board: John M. DAwson, University of Delaware; Gustave A. Harken, University of Florida; SAMUEL RothsteIN, University of British Columbia; JAMES E. SkipPER, University of California, Berkeley; Norman E. Tants, Kansas State College of Pittsburg; Maurice F. Tauber, Columbia University; Erleen Thonnton, Oberlin College.

ACRL Officers, 1968/69: President, David Kaser; Chairman, College Libraries Section, Evan Ira Farber; Junior College Libraries Section, Shirley A. Edsall; Rare Books Section, J. M. Edelstein; Subject Specialists Section, Thomas D. Gillies; Agriculture and Biological Sciences Subsection, Louise Darling; Art Subsection, Herbert G. Scherer; Law and Political Science Subsection, Morris L. Cohen; Slavic and East European Subsection, Dmytro M. Shtohryn; University Libraries Section, G. F. Shepherd.

News from the Field, Personnel profiles and notes, classified advertising, official matter of ACRL, and other material of a timely nature is published in the News issues of College \& Research Libraries.

Inclusion of an article or advertisement in CRL does not constitute official endorsement by ACRL or ALA.

Production and Advertising and Circulation office: 50 E. Huron St., Chicago, III. 60611. Change of address and orders for subscriptions should be addressed to College of Research Libraries, for receipt at the above address, at least two months before the publication date of the effective issue.

Subscription to $C R L$ is included in membership dues to $A C R L$ of $\$ 6$ or more; other subscriptions to $C R L$ are $\$ 10$ per year. Neither subscriptions nor memberships include miscellaneous unscheduled supplements, which are available by purchase only. Retroactive subscriptions are not accepted. Single journal copies are available at $\$ 1.50$ each and News issues at $\$ 1.00$ each from ALA Publishing Department.

Indexed in Library Literature. Abstracted in Library Science Abstracts. Book reviews indexed in Book Review Index.

College \& Research Libraries is the official journal of the Association of College and Research Libraries, a division of the American Library Association; and is published seventeen times per year-bi-monthly as a technical journal with 11 monthly News issues, combining July-August-at 1201-05 Bluff St., Fulton, Mo. 65251 .

Second-class postage paid at Fulton, Mo. 